\title{
Quality characteristics and biological activity of Yanggaeng with Glechoma hederacea var. longituba Nakai powder
}

\author{
Su-Bin Lim ${ }^{1}$, Ki-Tae Park ${ }^{2}$, Eun-Ho Lee ${ }^{1}$, Byung-Oh Kim ${ }^{1}$ Seon-Ho Lee ${ }^{3}$, \\ In-Kyu Kang ${ }^{4}$, Young-Je Cho ${ }^{1 *}$ \\ ${ }^{1}$ School of Food science and Biotechnology/Food and Bio-industry Research Institute, Kyungpook National University, \\ Daegu 41566, Korea \\ ${ }^{2}$ School of Culinary Art and Baking technology, Dongju College University, Busan 49318, Korea \\ ${ }^{3}$ Department of Food Science and technology, Yeungnam University, Gyeongsan 38541, Korea \\ ${ }^{4}$ Department of Horicultural Science, Kyungpook National University, Daegu 41566, Korea
}

\section{긴병꽃풀의 생리활성과 이를 첨가한 양갱의 품질특성}

\author{
임수빈 ${ }^{1} \cdot$ 박기태 $^{2} \cdot$ 이은호 ${ }^{1} \cdot$ 김병오 $^{1} \cdot$ 이선호 $^{3} \cdot$ 강인규 $^{4} \cdot$ 조영제 $^{1 *}$ \\ ${ }^{1}$ 경북대학교 식품공학부/식품생물산업연구소, ${ }^{2}$ 동주대학교 외식조리제과계열, ${ }^{3}$ 영남대학교 식품가공학과, \\ ${ }^{4}$ 경북대학교 원예과학과
}

\begin{abstract}
The objective of this study is to investigate the quality characteristics of Yanggaeng by using the functional properties of Glechoma hederacea (GH). Sample was dried at $50^{\circ} \mathrm{C}$ dry oven. The results of the study were as follows : The Phenolic compounds of GH was $12.99 \pm 0.3 \mathrm{mg} / \mathrm{g}$ in water extract (GHWE), $3.14 \pm 0.07 \mathrm{mg} / \mathrm{g}$ in $70 \%$ ethanol extract (GHEE). The antioxidant activity of GH was determined in various phenolic concentrations at $50-200 \mathrm{\mu g} / \mathrm{mL}$. DPPH activities of GHWE and GHEE were 77.16-78.24\% and 73.04-77.00\%, respectively. The ABTS were 84.35-99.75\% and 83.74-99.55\%. The anti-oxidant protection factor (PF) were 1.54-1.62 PF and 1.62-2.09 PF and TBARS were $42.93-94.09 \%$ and $91.05-95.19 \%$, respectively. Tyrosinase inhibitory activity of GHEE increased concentration dependently. Hyaluronidase inhibition activity of GHEE and GHWE, showing that there were increasing pattern depending on the increases in the phenolics concentration of GH. In texture, Hardness and springiness were significantly different in the control and $2 \%$ groups, but cohesiveness and chewiness did not show any significant difference. In color, $L$ value decreased in proportion to concentration, and a and $b$ values did not change. Sensory characteristics showed that the $1 \%$ group had the highest score and the $2 \%$ group had the lowest score. Thus, when the GHP Yanggaeng was prepared, in consideration of its sensory characteristics, and at appropriate concentration on below $1 \%$.
\end{abstract}

Key words : quality characteristics, Glechoma hederacea, Yanggaeng, powder, biological activity

\section{서 론}

최근 합성 화합물의 부작용과 독성의 발현 사례 증가로 인해 소비자들 사이에서 좀 더 안전하고 건강에 좋은 소재

*Corresponding author. E-mail : yjcho@knu.ac.kr

Phone : 82-53-950-7755, Fax : 82-53-950-7762

Received 22 November 2016; Revised 23 January 2017; Accepted 27 March 2017.

Copyright (c) The Korean Society of Food Preservation. All rights reserved.
를 사용하고자 하는 생각이 널리 퍼지고 있어 천연물을 사용한 제품에 대한 선호도가 높아지고 있다. 천연물 중 약용소재는 일반적으로 한약재 소재와 같이 오래전부터 사용되었기 때문에 안전성 검증 과정이 간소화 되어있고 신뢰도가 높으며, 최근의 연구보고에 의하면 천연물 중에 포함되어있는 다양한 생리활성 성분들이 알려지고 있어 더욱 소비자들의 관심과 신뢰를 받고 있다(1). 이러한 천연 물 소재의 생리활성 성분을 함유한 제품들이 꾸준히 개발되 고 있으며, 현재의 천연물 제품 시장에서는 천연물의약품 과 건강기능식품이 주를 이루고 있는 실정이다. 이에 천연 
물 소재의 성분을 이용한 가공식품 또한 높은 인기를 끌고 있으며, 천연물을 이용한 가공식품으로는 즉석밥, 음료, 빵 또는 과자 등의 다양한 제품들이 개발되고 있다 $(2,3)$.

양갱은 우리나라에서 생산되고 있는 한과의 한 종류로서 바다에서 채취한 한천을 주원료로 이용하여 설탕, 올리고 당, 팥 앙금 및 각종 과실을 첨가하여 조린 후 굳히는 과정으 로 제조하며 부드러운 조직감과 독특한 향을 가진 후식으로 이용되고 있다. 양갱 제조 시 응고제로 사용되는 한천은 해조류 유래 다당으로 대부분 식이섬유로 구성되어 있기 때문에 저칼로리이며, 체내에서 소화 및 흡수가 쉽게 이루 어지지 않아 포만감을 주고 장내 연동운동을 도와 변비에도 매우 효과가 좋은 식재료이다(4-7).

긴병꽃풀(Glechoma hederacea var. longituba Nakai)은 꿀 풀과(Lamiaceae)내의 박하족(tribementheae), 개박하아족 (subtribe Nepetinae)에 속하는 다년생 초본으로 아시아, 유 럽, 미국 등에 약 8종이 분포하고 있으며, 활혈단, 연전초, 네페타, 마제초라는 이명으로도 불린다(8). 긴병꽃풀은 덩 굴모양으로 신장하여 높이는 $20 \mathrm{~cm}$ 안팎이고 4-5월에 홍자 색 또는 연한 자주색을 나타낸다. 민간에서는 관상용과 약 용으로 쓰며, 어린잎은 식용 가능하고, 전초는 발한, 이뇨, 해열, 황달, 해독, 수종 등에 사용한다고 알려져 있다(9). 긴병꽃풀의 생리활성에 관한 선행연구로는 면역억제 효과 (10), 항염증 효과(11), $\mathrm{Na}^{+}-\mathrm{K}^{+}-\mathrm{ATPase}$ 억제력(12), 신장결석 생성 억제 효과(13), galactosamine 중독 흰쥐의 대사효소 활성(14) 등이 보고되고 있다. 긴병꽃풀의 성분으로는 3-Oa-L-rhamnopyranosyl, (1-2)- $\beta$-D-galactopyranosyl, schaftoside, soya-saponin 1, vicenin 1, vicenin 3 등이 함유되어 있다고 보고되고 있다(15).

따라서 본 연구에서는 긴병꽃풀 추출물의 항산화, 미백, 항염증 등의 생리활성 효과를 검증하고 긴병꽃풀 분말을 이용하여 제조된 긴병꽃풀 양갱의 기계적 성질과 색도 특성 을 비교하여 적정 배합비를 조사하고 더 나아가 관능평가를 통하여 선호도가 좋은 기능성 양갱을 제조하고자 하였다.

\section{재료 및 방법}

\section{실험 재료}

본 연구에 사용된 긴병꽃풀은 2014년도 4월에 대구 팔공 산 인근 들판에서 직접 채취하여 이물질을 제거한 후 사용 하였으며, 백앙금(Goodmorning Seoul, Seoul, Korea), 분말 한천(MSC, Yangsan, Korea), 올리고당(CJ CheilJedang, Incheon, Korea) 및 소금(SajoHaepyo, Seoul, Korea)은 시중 에서 구입하여 사용하였다.

\section{긴병꽃풀 분말 및 추출물 제조}

긴병꽃풀 분말은 $50^{\circ} \mathrm{C}$ drying oven에서 건조하여 40 mesh 크기로 분쇄하였으며, $4^{\circ} \mathrm{C}$ 에서 저온 저장하며 시료로 사용
하였다. 추출물 제조는 열수추출물의 경우 긴병꽃풀 분말 $1 \mathrm{~g}$ 에 증류수 $200 \mathrm{~mL}$ 를 가하고 $100 \mathrm{~mL}$ 가 될 때까지 가열하 여 끓인 후 상온에서 $120 \mathrm{rpm}$ 으로 교반 추출하였으며, ethanol 추출물은 긴병꽃풀 분말 $1 \mathrm{~g}$ 에 $100 \mathrm{~mL}$ 의 $70 \%$ ethanol을 추출용매로 가하여 24시간 동안 상온에서 120 $\mathrm{rpm}$ 으로 교반 추출하였다. 추출액은 Whatman No. 41 filter paper(GE Helathcare Life Science, New York, NY, USA)로 여과한 후 필요에 따라 rotary vacuum evaporator(BUCHI, Uster, Switzerland)로 농축하여 시료로 사용하였다.

\section{총 페놀 (phenol)성 화합물 정량}

총 페놀성 화합물(total phenolic content, TPC) 정량은 Folin-Denis 방법(16)에 준하여 측정하였으며, 시료 $1 \mathrm{~mL}$ 에 $95 \%$ ethanol $1 \mathrm{~mL}$ 와 증류수 $5 \mathrm{~mL}$ 를 첨가하고 $1 \mathrm{~N}$ Folin-ciocalteu reagent(Junsei, Tokyo, Japan) $0.5 \mathrm{~mL}$ 를 섞어 $\mathrm{Na}_{2} \mathrm{CO}_{3} 1 \mathrm{~mL}$ 를 가하여 1 시간 동안 암실에 방치한 후, 725 $\mathrm{nm}$ 의 파장으로 흡광도를 측정하여 gallic acid를 이용한 표 준곡선으로부터 양을 환산하여 $\mathrm{mg}$ gallic acid equivalent $(\mathrm{GAE} \mathrm{mg} / \mathrm{g})$ 으로 나타내었다.

\section{항산화 효과 측정}

1,1-diphenyl-2-picrylhydrazyl(DPPH) radical에 대한 소거 활성은 Blois의 방법(17)에 준하여 측정하였으며, 전자공여 능(\%)은 1-(반응구의 흡광도/대조구의 흡광도) $\times 100$ 으로 나 타내었다. 2,2'-Azinobis-(3-ethylbenzothiazoline-6-sulfonic acid) (ABTS) radical cation decolorization의 측정은 Fellegrin 등의 방법(18)에 준하여 측정하였고, 저해율(\%)은 1-(반응 구의 흡광도/대조구의 흡광도) $\times 100$ 으로 나타내었다. Antioxidant protection factor $(\mathrm{PF})$ 는 Andarwulan과 Shetty의 방법(19)에 준하여 측정하였으며, $\mathrm{PF}$ 는 (반응구의 흡광도/ 대조구의 흡광도)의 비로 나타내었다. Thiobarbituric acid reactive substance(TBARs) 측정은 Buege와 Aust의 방법(20) 에 준하여 측정하여 저해율(\%)은 1-(반응구의 TBARs $\mu \mathrm{M} /$ 대조구의 TBARs $\mu \mathrm{M}) \times 100$ 으로 나타내었다.

\section{미백(tyrosinase 저해) 활성 측정}

Tyrosinase 저해활성은 Vincent와 Hearing(21)의 방법에 준하여 측정하였다. 반응구는 $0.1 \mathrm{M}$ sodium phosphate buffer(pH 6.8) $2.3 \mathrm{~mL}$ 와 기질액 $1.5 \mathrm{mM} \mathrm{L-tyrosine} \mathrm{용액}$ $0.4 \mathrm{~mL}$ 의 혼합액에 $250 \mathrm{U} / \mathrm{mL}$ mushroom tyrosinase (Sigma-Aldrich Co., St. Louis, MO, USA) $0.1 \mathrm{~mL}$ 와 50-200 $\mathrm{\mu g} / \mathrm{mL}$ phenolic compounds 농도의 시료 $0.2 \mathrm{~mL}$ 를 넣고 대조 구는 시료 대신 증류수 $0.2 \mathrm{~mL}$ 를 넣어 $37^{\circ} \mathrm{C}$ 에서 20 분간 반응시켜 흡광도 $475 \mathrm{~nm}$ 에서 측정하여, 저해율(\%)은 (1-시 료의 흡광도/대조구의 흡광도) $\times 100$ 으로 계산하였다.

염증억제(hyaluronidase 저해)활성 측정

Hyaluronidase(HAase) 저해활성은 Dorfman A의 방법 
(22)에 준하여 측정하였다. 반응구는 시료 $0.5 \mathrm{~mL}$ 에 $20 \mathrm{mM}$ sodium phosphate buffer(pH 6.9)에 녹인 HAase $(1,000 \mathrm{U} / \mathrm{mL})$ $0.5 \mathrm{~mL}$ 을 혼합하여 $38^{\circ} \mathrm{C}$ 에서 5 분간 반응시키고 $0.3 \mathrm{M}$ phosphate buffer(pH 5.3)에 녹인 기질 $(4 \mathrm{mg} / \mathrm{mL}) 0.5 \mathrm{~mL}$ 을 넣어 다시 $38^{\circ} \mathrm{C}$ 에서 45 분간 반응시킨 후 $0.04 \mathrm{M}$ acetate buffer(pH 3.75)에 녹인 알부민용액 $5 \mathrm{~mL}$ 을 첨가한 후 5 분간 방치하고 $600 \mathrm{~nm}$ 에서 투과율을 측정하였다. 대조구는 시료 대신 증류수 $0.5 \mathrm{~mL}$ 를 넣어 반응시켰다. 저해율(\%)은 (1-시 료의 투과율/대조구의 투과율) $\times 100$ 으로 계산하였다.

\section{긴병꽃풀 분말을 첨가한 양갱의 제조}

긴병꽃풀 분말을 첨가한 양갱의 제조방법은 $\mathrm{Kim}$ 등(23) 의 방법을 참고하여 긴병꽃풀 분말의 첨가비율을 양갱에 첨가되는 앙금 대비 $0.5,1.0,1.5,2.0 \%$ 로 정하였다. 양갱의 제조방법은 Table 1 의 재료 배합 비율로 한천을 30 분간 따뜻한 물에 불리고 $85^{\circ} \mathrm{C}$ 에서 가열하여 녹인 후, 소금, 긴병 꽃풀 분말(앙금대비 $0.5,1.0,1.5,2.0 \%$ )을 넣고 녹인다. 백앙 금, 올리고당을 넣고 약한 불에 5 분 가열한 것을 양갱 틀에 부어 실온에서 굳힌 후, $4^{\circ} \mathrm{C}$ 에서 15 시간 냉각시키고, 실온에 서 1 시간 동안 방치 시킨 뒤 사용하였다.

Table 1. Formulas for preparation of yanggaeng with Glechoma hederacea powder

\begin{tabular}{cccccc}
\hline \multirow{2}{*}{ Ingredients } & \multirow{3}{c}{ Powder content $(\%, \mathrm{w} / \mathrm{w})$} \\
\cline { 3 - 6 } & & 0.5 & 1.0 & 1.5 & 2.0 \\
\hline White bean paste & 300 & 298.5 & 297 & 295.5 & 294 \\
Glechoma hederacea powder & 0 & 1.5 & 3.0 & 4.5 & 6.0 \\
Oligosaccharide & 30 & 30 & 30 & 30 & 30 \\
Agar powder & 9 & 9 & 9 & 9 & 9 \\
Salt & 0.6 & 0.6 & 0.6 & 0.6 & 0.6 \\
Water & 180 & 180 & 180 & 180 & 180 \\
\hline
\end{tabular}

\section{긴병꽃풀 분말을 첨가한 양갱의 색도측정}

양갱의 색도는 색차계(JP/CR series, Minolta Co., Osaka, Japan)를 사용하여 명도(L, lightness), 적색도(a, redness), 황색도(b, yellowness)를 측정하였고, 각 처리군당 6 개의 시 료를 사용하여 평균값을 이용하였다.

\section{긴병꽃풀 분말을 첨가한 양갱의 기계적 조직감 측정}

양갱의 기계적 조직감은 rheometer(Compac-100, Sun Science Co., Tokyo, Japan)를 사용하여 경도(hardness), 탄력 성(springiness), 응집성(cohesiveness), 씹힘성(chewiness)을 측정하였고, 측정 시 사용된 조건은 test type: texture, sample height: $10 \mathrm{~mm}$, sample width: $15 \mathrm{~mm}$, adaptor type: circle, adaptor area(diameter): $5 \mathrm{~mm}$, table speed: $120 \mathrm{~mm} / \mathrm{min}$ 이다.
긴병꽃풀 분말을 첨가한 양갱의 관능적 기호도 평가

긴병꽃풀 분말을 첨가한 양갱의 관능적 기호도 평가는 냉장 보관된 양갱을 실온에 방치하여 일정한 크기(15 $\mathrm{mm} \times 15 \mathrm{~mm} \times 10 \mathrm{~mm}$ )로 절단하여 식품응용공학과 학생 19 명을 대상으로 실시하였다. 평가항목으로는 맛, 향, 점성, 경도, 씹힘성, 탄력성, 전체적 기호도로 분류했으며, 5 점척 도법(1점, 매우 싫다; 2점, 약간 싫다; 3점, 좋지도 싫지도 않다; 4점, 약간 좋다, 5 점, 매우 좋다)을 사용하여 평가하였 다.

\section{통계처리}

모든 실험은 3회 이상 반복 측정하였고 자료의 통계처리 는 IBM SPSS statistics ver. 22 for windows(IBM Corp., Armonk, New York, NY, USA)를 이용하여 평균표표준편차 (mean $\pm \mathrm{SD}$ )로 표시하였고 분산분석(ANOVA)과 Duncan's multiple range test를 실시하여 시료간의 유의차를 $\mathrm{p}<0.05$ 수준으로 비교 분석하였다.

\section{결과 및 고찰}

\section{긴병꽃풀 추출물의 페놀성 화합물 함량 측정}

식물체에 함유되어있는 페놀성 화합물들은 식물체의 2 차 대사산물로서 항암, 항산화 작용, 정장작용, 콜레스테롤 저하작용 등의 다양한 생리활성 기능을 가지고 있다. 이들 은 다양한 구조와 분자량을 가지고 있어 생리활성 또한 매우 다르게 나타나는데, 이것은 분자내의 phenolic hydroxyl기가 효소 단백질과 같은 거대분자들과 결합하는 특성이 있어 뛰어난 활성을 나타낸다. 항산화 작용과 관련 하여 최근 생체 내에서의 산소 free radical 반응이 생체조직 의 노화나 질병과 관련이 있으며, 페놀성 물질의 hydroxyl group은 유지의 유리기 수용체로서 유지 산패의 초기 단계 에 생성된 유리기들이 안정된 화합물을 형성하도록 하여 항산화 작용을 한다고 알려져 있다(24). 본 연구에서는 이러 한 생리활성 기능을 가지는 페놀성 화합물을 추출하기 위하 여 식품에 적용할 수 있는 용매로 물과 ethanol을 이용하여 추출해서 gallic acid 표준곡선을 이용하여 정량하였다. 그 결과 Fig. 1 에서와 같이 열수추출물에서 $12.99 \mathrm{GAE} \mathrm{mg} / \mathrm{g}$ 으 로 가장 높은 추출 수율을 나타내었고, ethanol에서 3.14 $\mathrm{GAE} \mathrm{mg} / \mathrm{g}$ 의 용출량을 나타내었다.

\section{긴병꽃풀 추출물의 항산화 효과}

$\mathrm{DPPH}$ radical 소거능 측정은 안정한 형태의 DPPH radical 에 시료의 페놀성 화합물이 수소공여작용을 통하여 DPPH-H 의 형태로 환원시키면 흡광도가 감소하는 것을 이용한 항산 화 효과 검증 방법이다(25). 긴병꽃풀 추출물의 전자공여능 을 측정한 결과 Fig. $2 \mathrm{~A}$ 에서와 같이 열수추출물은 50-200 
$\mu \mathrm{g} / \mathrm{mL}$ 의 $\mathrm{TPC}$ 농도에서 $77.16-78.24 \%$ 의 전자공여능을 나 타내었고, $70 \%$ ethanol 추출물에서는 73.04-77.00\%로 나타 내었다. Positive control로 사용한 BHT에서는 50-200 $\mu \mathrm{g} / \mathrm{mL}$

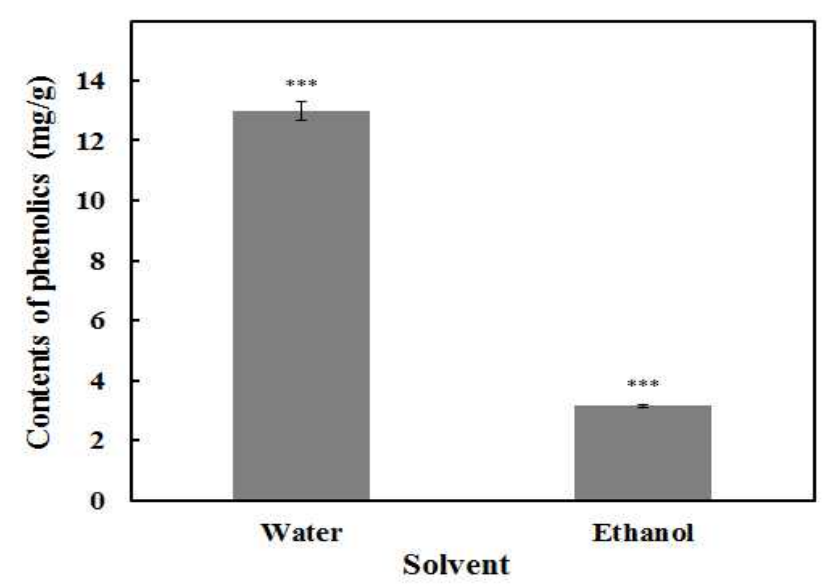

Fig. 1. Content of phenolics in water and ethanol extracts from Glechoma hederacea.

$* * *, \mathrm{p}<0.001$.
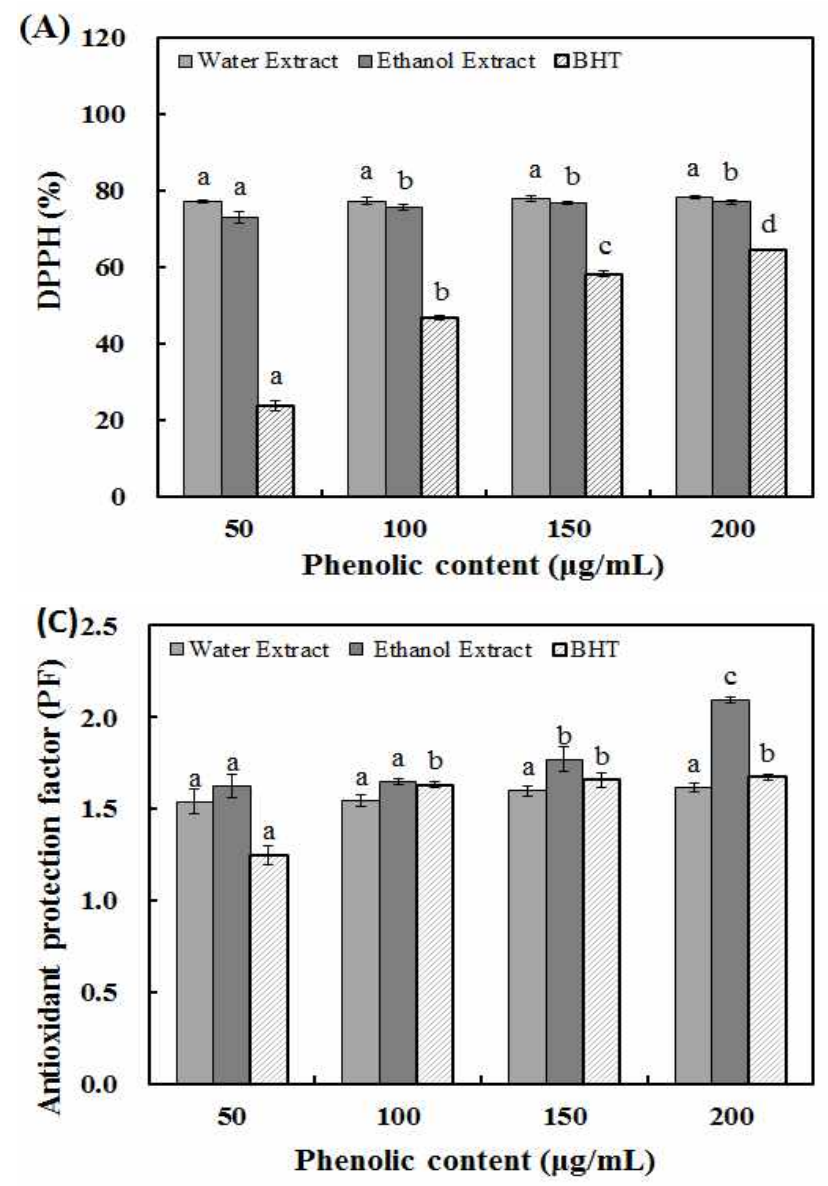

의 농도에서 23.78-64.72\%로 긴병꽃풀 추출물보다 비교적 낮은 전자공여능을 나타내었다. $\mathrm{Kim}$ 등(26)은 모시풀잎 $70 \%$ ethanol 추출물을 $52.5 \mathrm{\mu g} / \mathrm{mL}$ 농도로 측정한 결과 $71.6 \%$ 의 전자공여능을 나타내었다고 보고한 결과에 비해 긴병꽃풀의 전자공여능이 더 우수하다고 판단되었다. 긴병 꽃풀 추출물의 $\mathrm{ABTS}$ radical 소거능을 측정한 결과 Fig. 2B에서와 같이 열수추출물은 $50-200 \mu \mathrm{g} / \mathrm{mL}$ 의 TPC 농도에 서 84.35-99.75\%의 radical 소거능을 나타내었고, $70 \%$ ethanol 추출물에서는 83.74-99.55\%로 50-100 $\mu \mathrm{g} / \mathrm{mL}$ 의 구 간에서는 증가하였으나, 더 높은 농도에서는 유의적 차이 를 나타내지 않았다. $\mathrm{Bae}$ 등(27)은 $62.5 \mu \mathrm{g} / \mathrm{mL}$ 농도의 생강 열수, $80 \%$ ethanol 추출물에서 각각 $59.7 \%, 39.0 \%$ 의 소거능 을 나타내었다고 보고한 결과와 비교하였을 때 긴병꽃풀의 ABTS radical 소거능이 더 우수하다고 판단되었다. Positive control로 사용한 BHT에서는 $50-200 \mu \mathrm{g} / \mathrm{mL}$ 의 농도에서 26.09-90.97\%의 소거능을 나타내어 긴병꽃풀 추출물이 합 성항산화제를 대체할 수 있는 소재로 적합하다고 판단되었 다. $\beta$-Carotene linoleate system을 통한 항산화 효과의 측정
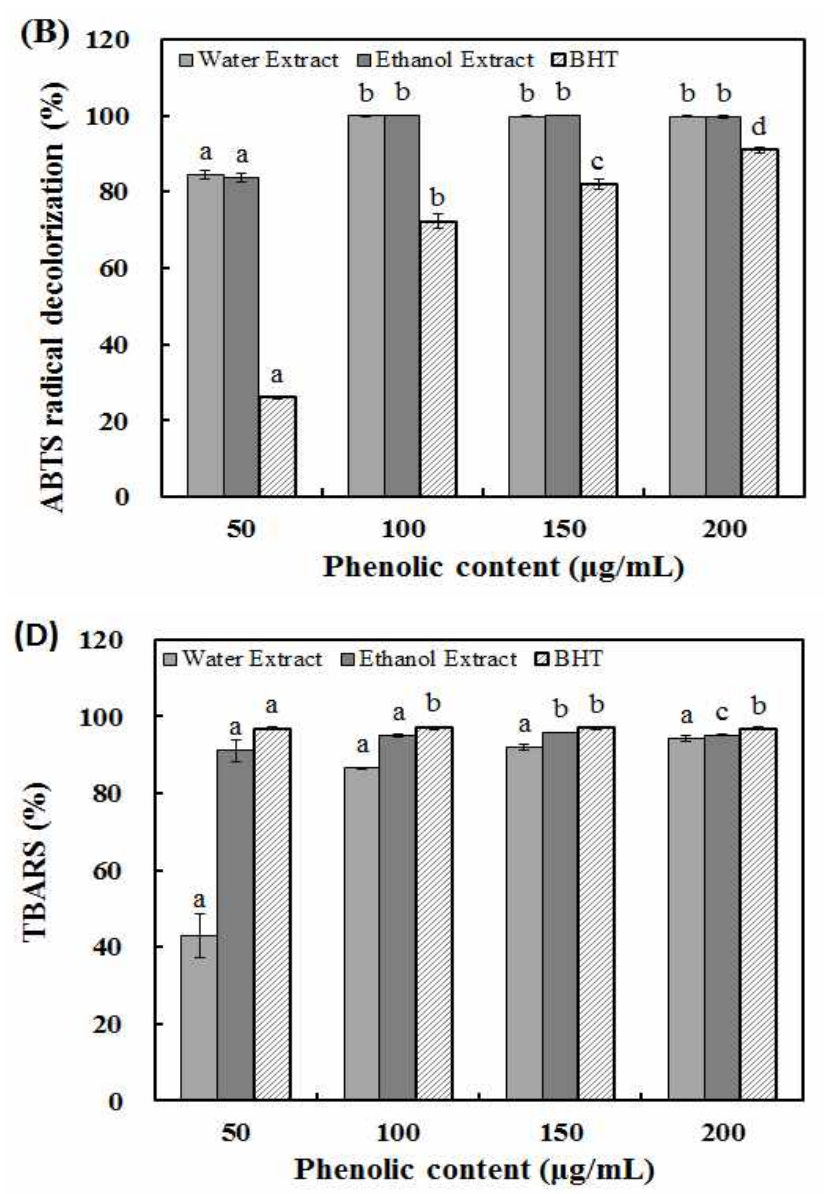

Fig. 2. Antioxidant activity of water and 70\% ethanol extract from Glechoma hederacea.

A, DPPH; B, ABTS; C, antioxidant protection factor; D, TBARs.

Values with different alphabet in the column were significantly different among group at $\mathrm{p}<0.05$ level by a Duncan's multiple range test. 
방법은 지방산패의 특징을 이용하여 불포화지방산으로부 터 생성된 free radical이 $\beta$-carotene의 특징적인 색을 감소시 키는 것을 측정하는 방법(28)으로 긴병꽃풀의 지용성 항산 화 효과를 측정하는 antioxidant protection factor(PF)를 측정 한 결과 Fig. $2 \mathrm{C}$ 에서와 같이 열수추출물은 $50-200 \mu \mathrm{g} / \mathrm{mL}$ 의 TPC 농도에서 1.54-1.62 PF를 나타내었고, 70\% ethanol 추 출물에서는 1.62-2.09 PF를 나타내어 $50-200 \mathrm{\mu g} / \mathrm{mL}$ 의 농도 에서 1.25-1.68 PF를 나타낸 BHT보다 더 우수한 효능을 나타내었다. Park 등(29)은 약용식물인 지유, 천문동, 천련 자, 청피 열수추출물을 $200 \mu \mathrm{gg} / \mathrm{mL}$ 의 농도로 측정한 결과 각각 $0.9,1.7,1.3,1.1 \mathrm{PF}$ 를 나타내었다고 보고한 결과와 비교하였을 때, 긴병꽃풀 추출물의 지용성 항산화 효과가 더 우수하다고 판단되었다. 지방의 자동산패 과정에서 생 성된 free radical은 산소와 반응하여 과산화물인 peroxy radical을 생성한다. 이것은 다시 여러 반응을 거쳐 hydroperoxide로 변하며 이는 1,1,3,3-tetraethoxypropane (TEP)를 거쳐 결과적으로 malonic dialdehyde(MDA), ethane, pentane 등을 생성한다. Thiobarbituric acid reactive substance (TBARs)는 여기서 생성된 MDA를 thiobarbituric acid와 산 성 조건하에서 반응시켜서 특징적인 색을 나타내어 지방산 패 억제능을 측정하는 방법(30)으로 긴병꽃풀 추출물의 TBARs를 측정한 결과 Fig. $2 \mathrm{D}$ 에서와 같이 열수추출물은 $50-200 \mu \mathrm{g} / \mathrm{mL}$ 의 TPC 농도에서 42.93-94.09\%를 나타내었 고, $70 \%$ ethanol 추출물에서는 91.05-95.19\%로 높은 활성을 나타내어 부작용을 발생시킬 수 있는 BHT보다 긴병꽃풀 추출물이 더 우수하다고 확인할 수 있었다. Jung 등(31)은 무 줄기, 뿌리 $50 \%$ ethanol 추출물을 $200 \mathrm{\mu g} / \mathrm{mL}$ 의 농도에서 측정한 결과 각각 $26.8,37.7 \%$ 의 TBARs를 나타내었다고 보고한 결과와 비교하였을 때, 긴병꽃풀의 지방산패 억제 능이 더 우수하다고 판단되었다.

\section{긴병꽃풀 추출물의 미백(tyrosinase 저해) 활성}

Melanocyte는 피부 기저층에 존재하는 세포로서 melanosome 을 통하여 melanin을 생성하고 melanin을 이용하여 태양 자외선으로부터 피부를 보호하는 역할을 한다. 하지만 melanin의 생성이 과다하게 일어나면 흑생종과 피부 색소 침착 등을 일으킬 수 있어 생성량에 조절이 필요하다. 이 과정에서 가장 중요한 역할을 하는 효소인 tyrosinase는 tyrosine을 산화시켜 3,4-dihydroxyphenylalanin(DOPA)를 생성하고 DOPA는 또 tyrosinase에 의하여 DOPA quinone으 로 변환된다. 이는 또 다른 단백질들의 작용에 의하여 최종 적으로 pheomelanin과 eumelanin으로 변환되어 turnover에 의하여 표피로 이동한다. 이 과정에서 melanin이 과도하게 쌓이면 색소침착이 일어나게 된다. 이처럼 tyrosinase는 melanin 생성 초기단계에서 가장 중요한 역할을 하는 효소 이기 때문에 미백 효과 측정에서 tyrosinase 저해활성이 가 장 많이 사용되고 있다(32). 긴병꽃풀 추출물의 tyrosinase
저해활성을 측정한 결과 Fig. 3에서와 같이 열수추출물에서 는 저해활성이 나타나지 않았으며, $70 \%$ ethanol 추출물에서 는 $50-200 \mathrm{\mu g} / \mathrm{mL}$ 의 TPC 농도에서 $30.32-40.56 \%$ 의 tyrosinase 저해활성을 나타내었다. Kojic acid는 tyrosinase의 활성을 저해하여 미백효과를 나타낼 수 있어 화장품에 사용되고있 는 물질로서 positive control로 사용하였다(33). Kojic acid에 서는 58.84-87.95\%의 tyrosinase 저해활성을 나타내었다. Yoon(33)은 땅콩새싹 $95 \%$ ethanol 추출물이 $100 \mu \mathrm{g} / \mathrm{mL}$ 의 농도에서 $23.0 \%$ 의 저해활성을 나타낸다고 보고한 결과와 비교하였을 때 긴병꽃풀 추출물의 tyrosinase 저해활성이 더 우수하였고 기능성 미백 화장품의 원료로도 이용 가능할 것으로 기대되어진다.

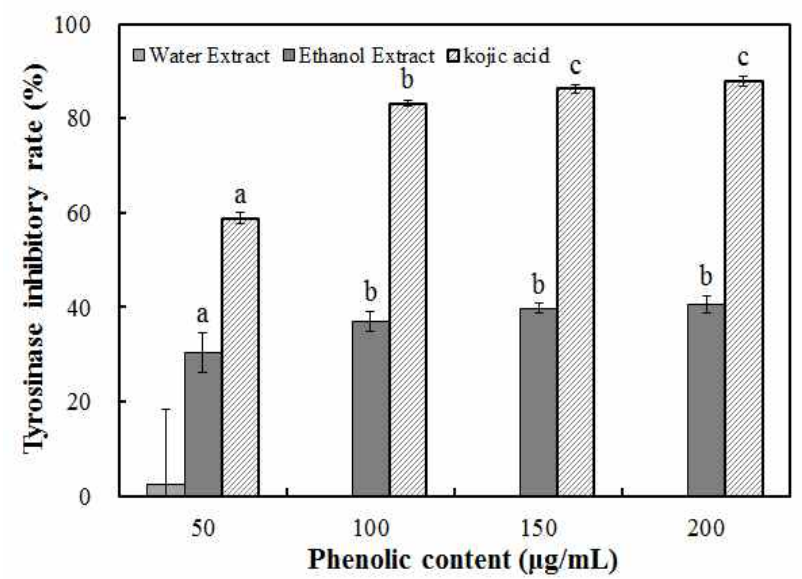

Fig. 3. Tyrosinase inhibitory activity of Glechoma hederacea extracts.

Values with different alphabet in the column were significantly different among group at $p<0.05$ level by a Duncan's multiple range test.

긴병꽃풀 추출물의 염증억제(hyaluronidase 저해)활성

Hyaluronidase(HAase)는 hyaluronic acid의 glucuronic acid와 N-acetylglucosamine의 $\beta-1,4$ 결합을 가수분해하는 효소이다. HAase에 의하여 생성된 분해생성물 혹은 저분자 의 hyaluronic acid는 염증을 유발하거나 fibrosis, collagen deposition을 증가시킨다고 알려져 있으며 항알러지 및 항 염증 약물인 disodium cromoglycate(DSCG), Tranilast, Traxanox 등에 의하여 그 활성이 저해됨이 보고되었다. 이 와 같이 염증과 HAase의 연관성이 알려져 있으며 HAase 활성저해는 다양한 물질의 항염증 활성 검색에 우선적으로 이용되고 있는 방법이다(34). 긴병꽃풀 추출물의 HAase 저 해활성을 측정한 결과 Fig. 4에서와 같이 열수추출물은 50-200 $\mu \mathrm{g} / \mathrm{mL}$ 의 TPC 농도에서 $14.23-40.93 \%$ 의 HAase 저해 활성을 나타내었고, $70 \%$ ethanol 추출물에서는 57.45-72.88 $\%$ 의 저해활성을 나타내었다. Positive control로 사용한 PDTC(ammonium pyrrolidine di-thiocarbamate)는 50-200 $\mu \mathrm{g} / \mathrm{mL}$ 의 농도에서 $5.49-98.21 \%$ 의 저해활성을 나타내었다. $\mathrm{Cho(35)는} \mathrm{쇠무릎} \mathrm{잎,} \mathrm{줄기,} \mathrm{뿌리} \mathrm{ethanol} \mathrm{추출물을} 500$ 
$\mu \mathrm{g} / \mathrm{mL}$ 의 농도로 HAase 저해활성을 측정한 결과 각각 $21.01,29.01,32.12 \%$ 의 저해활성을 나타낸다고 보고하였 다. 이와 비교하였을 때 긴병꽃풀의 HAase 저해활성이 더 우수하였고, 시판 중인 합성의약품의 부작용을 대체할 수 있는 천연물질로 이용할 수 있는 근거자료로 사용될 수 있다고 판단되었다.

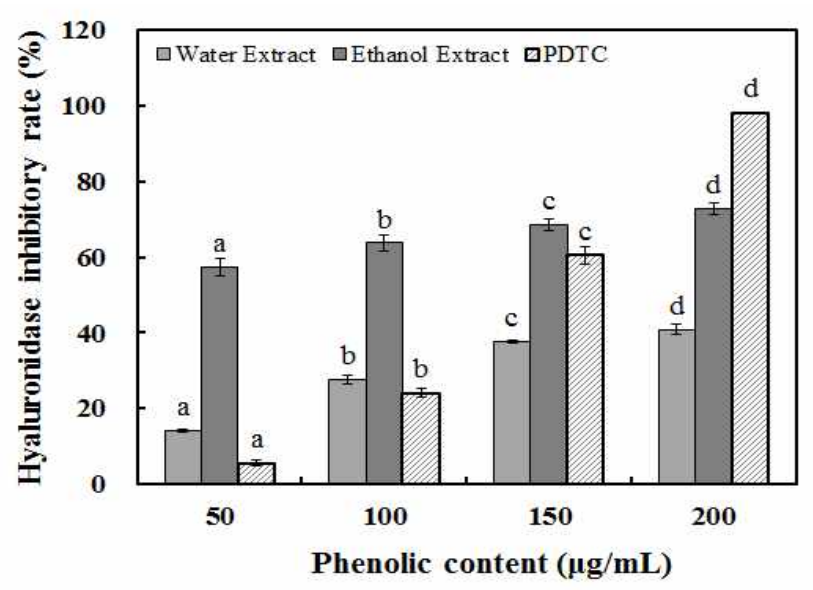

Fig. 4. Hyaluronidase inhibitory activity of Glechoma hederacea. Values with different alphabet in the column were significantly different among group at $p<0.05$ level by a Duncan's multiple range test.

\section{긴병꽃풀 분말을 첨가한 양갱의 색도}

긴병꽃풀 분말(0.5-2.0\%)을 첨가하여 제조한 양갱의 색 도 측정결과 Table 2 와 같이 명도를 나타내는 $\mathrm{L}$ 값은 대조군 이 48.92로 가장 높았고, 분말 첨가군의 농도에 따라 32.79-42.07의 범위로 대조군보다 낮게 나타났다. 따라서 긴병꽃풀 분말의 농도가 증가할수록 $\mathrm{L}$ 값은 감소하여 명도 가 낮아지는 경향을 나타내어, 분말 첨가군의 농도에 따른 유의적인 차이를 나타내었다. 적색도를 나타내는 a 값은 긴병꽃풀 분말의 첨가량이 증가함에 따라 유의적으로 감소 하는 결과를 나타내었다.

Table 2. Color value of Yanggaeng with various content of Glechoma hederacea powder

\begin{tabular}{ccccc}
\hline \multirow{2}{*}{$\begin{array}{c}\text { Powder content } \\
(\%)\end{array}$} & \multicolumn{4}{c}{ Color value $^{1)}$} \\
\cline { 2 - 5 } & $\mathrm{L}$ & $\mathrm{a}$ & $\mathrm{b}$ & $\Delta \mathrm{E}$ \\
\hline Control & $48.92 \pm 2.88^{2 \mathrm{a} a 3)}$ & $-0.23 \pm 0.08^{\mathrm{a} 6)}$ & $11.08 \pm 0.99^{\mathrm{a}}$ & 0 \\
0.5 & $42.07 \pm 2.44^{\mathrm{b}}$ & $-0.58 \pm 0.08^{\mathrm{b}}$ & $11.09 \pm 0.95^{\mathrm{a}}$ & 6.86 \\
1.0 & $37.97 \pm 2.26^{\mathrm{c}}$ & $-0.58 \pm 0.20^{\mathrm{b}}$ & $11.22 \pm 0.68^{\mathrm{a}}$ & 10.96 \\
1.5 & $36.45 \pm 1.18^{\mathrm{c}}$ & $-0.63 \pm 0.09^{\mathrm{bc}}$ & $11.03 \pm 0.69^{\mathrm{a}}$ & 12.48 \\
2.0 & $32.79 \pm 2.73^{\mathrm{d}}$ & $-0.73 \pm 0.09^{\mathrm{c}}$ & $10.09 \pm 0.87^{\mathrm{b}}$ & 16.17 \\
\hline
\end{tabular}

${ }^{1)} \mathrm{L}$-value, degree of lightness $(+100=$ white, $0=$ black); a-value, degree of redness $(+100=$ red, $-80=$ green); $b$-value, degree of yellowness $(+70=$ yellow, $-70=b l u e) ; \triangle E$, Overall color difference $\left([(\Delta \mathrm{L}) 2+(\Delta \mathrm{a}) 2+(\Delta \mathrm{b}) 2]^{\wedge} \frac{1}{2}\right)$.

${ }^{2)}$ Mean \pm SD.

${ }^{3)}$ Values with different alphabet in the column were significantly different among group at $p<0.05$ level by Duncan's multiple range test.
황색도를 나타내는 $\mathrm{b}$ 값은 긴병꽃풀 분말의 첨가군량에 관계없이 일정한 값을 나타내었다. 명도는 모든 구간에서 유사한 결과를 나타내었지만, $\mathrm{a}$ 값과 $\mathrm{b}$ 값에는 긴병꽃풀 분말이 어두운 녹색을 띠고 있어 첨가량이 증가하더라도 큰 영향을 미치지 않는 것으로 나타내었다. 긴병꽃풀 첨가 군의 색차를 측정한 결과, 대조군에 비해 분말 첨가군의 농도가 증가함에 따라 색차가 증가하는 결과를 나타내어 명도의 차이가 커짐으로 인해 발생한 결과로 예상되었다.

\section{긴병꽃풀 분말을 첨가한 양갱의 기계적 조직감}

긴병꽃풀 분말을 첨가하여 제조한 양갱의 기계적 조직감 을 측정한 결과 Table 3와 같이 hardness는 대조군이 6.41 $\mathrm{kg} / \mathrm{cm}^{2}$ 로 가장 높았으나 대조군과 $1.0 \%$ 첨가군까지는 유의 적 차이를 나타내지 않았고, $1.5 \%$ 이상 첨가군에서는 유의 적 차이를 나타내었다. 이 결과는 부재료의 첨가량이 증가 하여 한천에 의한 응고력이 감소한 결과로 사료된다. Springiness는 대조군이 $342.01 \%$ 로 가장 높았으며, $1.5 \%$ 첨가군까지 springiness가 감소하다가 $2.0 \%$ 첨가군에서는 일정한 결과를 보여 전체적으로 감소하는 경향을 나타내었 다. Cohesiveness는 대조군과 첨가군이 69.63-73.45\%로 긴 병꽃풀 분말 첨가량에 따른 유의적 차이가 없는 것으로 나타내었다. Chewiness는 $2.0 \%$ 에서 $169.53 \mathrm{~g}$ 으로 가장 높 았으며 대조군과 긴병꽃풀 분말 첨가군 사이에는 유의적 차이를 나타내지 않았다. 긴병꽃풀 분말의 첨가는 양갱의 기계적 특성에 영향을 미치는 것으로 나타내어 관능적 기호 도에 따라 첨가량을 결정하는 것이 적합하다고 판단되었 다.

Table 3. Texture of Yanggaeng with various content of Glechoma hederacea powder

\begin{tabular}{ccccc}
\hline \multirow{2}{*}{\begin{tabular}{c} 
Powder content $\begin{array}{c}\text { Texture } \\
(\%)\end{array}$ \\
\cline { 2 - 5 }
\end{tabular}} & $\begin{array}{c}\text { Hardness } \\
\left(\mathrm{kg} / \mathrm{cm}^{2}\right)\end{array}$ & $\begin{array}{c}\text { Springiness } \\
(\%)\end{array}$ & $\begin{array}{c}\text { Cohesiveness } \\
(\%)\end{array}$ & $\begin{array}{c}\text { Chewiness } \\
(\mathrm{g})\end{array}$ \\
\hline Control & $\left.6.41 \pm 0.29^{1 / 2)}\right)$ & $342.01 \pm 22.74^{\mathrm{a} 2)}$ & $71.08 \pm 5.25^{\mathrm{a}}$ & $158.39 \pm 14.01^{\mathrm{ab}}$ \\
0.5 & $5.99 \pm 0.29^{\mathrm{a}}$ & $334.98 \pm 13.75^{\mathrm{a}}$ & $72.54 \pm 2.32^{\mathrm{a}}$ & $146.64 \pm 5.57^{\mathrm{a}}$ \\
1.0 & $5.99 \pm 0.28^{\mathrm{a}}$ & $310.14 \pm 29.35^{\mathrm{a}}$ & $69.63 \pm 4.17^{\mathrm{a}}$ & $161.10 \pm 6.07^{\mathrm{ab}}$ \\
1.5 & $5.09 \pm 0.57^{\mathrm{b}}$ & $269.48 \pm 34.51^{\mathrm{b}}$ & $70.02 \pm 2.55^{\mathrm{a}}$ & $159.47 \pm 6.82^{\mathrm{ab}}$ \\
2.0 & $5.31 \pm 0.49^{\mathrm{b}}$ & $271.47 \pm 21.97^{\mathrm{b}}$ & $73.45 \pm 6.41^{\mathrm{a}}$ & $169.53 \pm 17.78^{\mathrm{b}}$ \\
\hline${ }^{1)}$ Mean \pm SD. \\
${ }^{2)}$ Values with different alphabet in the column were significantly different among group \\
at p<0.05 level by Duncan's multiple range test.
\end{tabular}

긴병꽃풀 분말을 첨가한 양갱의 제조 및 관능적 기호도 평가

긴병꽃풀 분말을 첨가한 양갱의 관능적 기호도 평가는 Table 4와 같이 viscosity는 대조군이 2.8점으로 가장 높은 점수로 평가 받았으며, 첨가군은 2.4-2.7점으로 비교적 낮은 평가를 받았다. 이는 긴병꽃풀 분말이 양갱의 수분함량을 
감소시켜 점도가 낮아진 결과로 판단되었다. Hardness는 대조군이 3.1점, 첨가군에서 2.9-3.1점으로 경도는 큰 차이 를 나타내지 않았다. Chewiness는 대조군이 3.6점으로 가장 높은 점수로 평가 받았으며, 첨가군은 2.6-3.2점으로 긴병꽃 풀 분말 첨가량이 증가할수록 씹힘성이 감소하는 경향을 나타내었다. Springiness는 대조군이 3.2점, 첨가군은 2.83.0점으로 탄력성에는 큰 차이를 나타내지 않았다. Taste는 대조군이 3.7점으로 가장 높은 점수로 평가 받았으며, 첨가 군에서는 $0.5 \%$ 와 $1.0 \%$ 첨가군이 비슷한 평가를 받았으며, 긴병꽃풀 분말의 첨가량이 증가함에 따라 taste 기호도가 감소하는 결과를 나타내었다. Flavor는 대조군이 3.1점, 첨 가군은 2.9-3.2점으로 향에는 큰 차이를 나타내지 않았다. Overall acceptabillity는 대조군이 3.5점으로 가장 높은 점수 로 평가받았다. $1.0 \%$ 첨가군이 두번째로 높은 점수를 받았 으며, 첨가량이 증가할수록 overall acceptabillity가 감소하 는 경향을 나타내었다. 긴병꽃풀 분말의 첨가는 식감의 기 호도에 많은 영향을 미치는 것으로 나타났으며, 맛과 향에 의해 큰 기호도 차이를 나타내었다. 첨가량이 증가함에 따 라 기호도가 감소하는 경향을 나타내었지만, $1.0 \%$ 첨가군 에서는 기호도에 대해 높은 평가를 받았기 때문에 기호도를 해치지 않는 $1.0 \%$ 이하의 분말을 첨가하는 것이 적합할 것으로 판단되었다.

Table 4. Sensory evaluation test of Yanggaeng with various contents of Glechoma hederacea powder

\begin{tabular}{cccccc}
\hline & \multicolumn{5}{c}{ Sensory evaluation score } \\
\cline { 2 - 6 } Item & Control & \multicolumn{4}{c}{ Powder content $(\%)$} \\
\cline { 2 - 5 } & & 0.5 & 1.0 & 1.5 & 2.0 \\
\hline Viscosity & $\left.2.8 \pm 0.6^{2 \mathrm{a} a}\right)$ & $2.7 \pm 0.7^{\mathrm{ab}}$ & $2.4 \pm 0.5^{\mathrm{ab}}$ & $2.4 \pm 0.6^{\mathrm{ab}}$ & $2.4 \pm 0.6^{\mathrm{b}}$ \\
Hardness & $3.1 \pm 0.9^{\mathrm{a}}$ & $3.1 \pm 0.9^{\mathrm{a}}$ & $3.1 \pm 0.7^{\mathrm{a}}$ & $2.9 \pm 0.8^{\mathrm{a}}$ & $2.9 \pm 0.9^{\mathrm{a}}$ \\
Chewiness & $3.6 \pm 0.9^{\mathrm{a}}$ & $3.2 \pm 0.8^{\mathrm{ab}}$ & $3.1 \pm 0.7^{\mathrm{ab}}$ & $2.9 \pm 1.1^{\mathrm{b}}$ & $2.6 \pm 1.1^{\mathrm{b}}$ \\
Springiness & $3.2 \pm 1.1^{\mathrm{a}}$ & $2.9 \pm 0.8^{\mathrm{a}}$ & $2.8 \pm 0.8^{\mathrm{a}}$ & $2.8 \pm 1.0^{\mathrm{a}}$ & $2.9 \pm 0.8^{\mathrm{a}}$ \\
Taste & $3.7 \pm 0.8^{\mathrm{a}}$ & $3.2 \pm 0.7^{\mathrm{ab}}$ & $3.2 \pm 0.8^{\mathrm{ab}}$ & $2.8 \pm 1.0^{\mathrm{b}}$ & $2.8 \pm 1.3^{\mathrm{b}}$ \\
Flavor & $3.1 \pm 0.5^{\mathrm{a}}$ & $3.2 \pm 0.6^{\mathrm{a}}$ & $3.2 \pm 0.6^{\mathrm{a}}$ & $3.1 \pm 0.7^{\mathrm{a}}$ & $2.9 \pm 0.7^{\mathrm{a}}$ \\
Overall acceptabillity & $3.5 \pm 0.5^{\mathrm{a}}$ & $3.0 \pm 0.7^{\mathrm{abc}}$ & $3.2 \pm 0.8^{\mathrm{ab}}$ & $2.8 \pm 0.8^{\mathrm{bc}}$ & $2.5 \pm 1.2^{\mathrm{c}}$ \\
\hline
\end{tabular}

${ }^{1)}$ Sensory evaluation was checked as very good (5 point), slightly good (4 point), normal (3 point), slightly bad (2 point), Very bad (1 point). ${ }^{2)} \mathrm{Mean} \pm \mathrm{SD}$.

${ }^{3)}$ Values with different alphabet in the column were significantly different among group at $\mathrm{p}<0.05$ level by Duncan's multiple range test.

\section{요 약}

본 연구에서는 긴병꽃풀의 항산화 효과와 기능성을 활용 한 양갱을 제조하여 기계적 특성을 측정하고, 관능적 기호 도 평가를 실시하였다. 생리활성 물질의 양을 측정하기 위 하여 페놀성 화합물 정량을 실시한 결과 긴병꽃풀 열수추출
물에서 $12.99 \pm 0.30 \mathrm{mg} / \mathrm{g}, 70 \%$ ethanol 추출물에서 $3.14 \pm 0.07$ $\mathrm{mg} / \mathrm{g}$ 으로 나타내었다. $50-200 \mathrm{\mu g} / \mathrm{mL}$ 의 농도에서 항산화 효과를 측정한 결과, 전자공여능은 열수추출물과 $70 \%$ ethanol 추출물에서 각각 77.16-78.24\%, 73.04-77.00\%로 나 타내었으며, ABTS는 84.35-99.75\%, 83.74-99.55\%로 나타 내었다. Antioxidant protection factor(PF)는 1.54-1.62, 1.62-2.09 PF를 나타내었으며, TBARs는 42.93-94.09\%, 91.05-95.19\%로 나타내었다. 긴병꽃풀 추출물의 열수추출 물과 $70 \%$ ethanol 추출물은 거의 비슷한 항산화 효과를 나타내었으나, $\mathrm{PF}$ 와 TBARs에서는 $70 \%$ ethanol 추출물에 서 더 우수한 항산화 효과를 나타내었다. Tyrosinase 저해활 성은 열수추출물에서는 효과가 나타나지 않았으며, $70 \%$ ethanol 추출물에서는 30.32-40.56\% 의 저해활성을 나타내 었다. Hyaluronidase 저해활성은 $14.23-40.93 \%, 57.45-72.88 \%$ 로 $70 \%$ ethanol 추출물이 더 우수한 저해활성을 나타내었으 며, $50-100 \mathrm{\mu g} / \mathrm{mL}$ 의 저농도에서는 positive control로 사용한 PDTC보다 우수한 저해활성을 나타내었다. 색도는 긴병꽃 풀 분말의 첨가량이 증가할수록 $\mathrm{L}$ 값과 $\mathrm{a}$ 값은 감소하는 경향을 나타내었고 $\mathrm{b}$ 값은 일정하게 나타내었다. 기계적 조직감은 경도와 탄력성에서 긴병꽃풀 분말의 첨가량이 증가할수록 감소하는 경향을 나타내었고, 응집성은 첨가량 과 관계없이 일정한 값을 나타내었다. 씹힘성은 $2.0 \%$ 에서 가장 높은 수치를 나타내었으나 대조군과 첨가군 간의 유의 적 차이는 나타나지 않았고, 긴병꽃풀 분말이 양갱의 기계 적 조직감에 영향을 준다는 것을 확인할 수 있었다. 긴병꽃 풀 분말 첨가 양갱의 관능적 기호도는 점도, 경도, 씹힘성, 탄력성, 맛, 향, 전반적인 기호도 항목에서 대조군을 제외하 고 $1.0 \%$ 이하 첨가군에서 기호도가 높게 나타내었으며 $2.0 \%$ 첨가군은 모든 항목에서 가장 낮은 기호도를 나타내 었다. 위 결과에 따라 긴병꽃풀 분말을 이용한 양갱 제조에 는 $1.0 \%$ 이하의 농도를 사용하여 제조하는 것이 가장 적합 하다고 판단되었다.

\section{References}

1. Lee YK (1995) Identification and antimicrobial activity of cinnamon and clove extracts on food spoilage microorganisms. Sookmyung Women's University, Korea, p 1-4

2. Lee MH, Jo DJ, Yoon SR, Lee GD (2007) Physicochemical properties of functional herb mixtures. J Korean Soc Food Sci Nutr, 36, 1571-1577

3. Choi GY, Bae JH, Han GJ (2007) The quality characteristics of sponge cake containing a functional and natural product (1. Mulberry leaf powder). J East Asian Soc Dietary Life, 17, 703-709 
4. Park MS (2008) A study on quality characteristics of Doraji (Platydodon grandiflorum) Yanggaeng by different pre-treatment methods and adding levels of Doraji. Dongguk University, Korea, p 1-3

5. Jung HS, Lee JS, Yoon HH (2014) Quality characteristics of Yanggaeng sweetened with trehalose and textural changes during storage. Culi Sci Hos Res, 20, 113-124

6. Choi EH, Kim DS, Choi SK, Park KB (2013) Optimization and quality characteristics of balsamic vinegar jelly with various gelling agents. Culi Sci Hos Res, 19, 151-163

7. Lee SH, Hong EJ, Cho YJ (2015) Quality characteristics of Yanggaeng with Momordica charantia powder. Korean J Food Preserv, 22, 335-344

8. Jang TS (2008) Systematics of the genus Glechoma L. and related genera (Nepetinae, Lamiaceae). Kyunghee University, Korea, p 2-4

9. Kim OK (2004) Antidiabetic effect of Glechoma hederacea LINNAEUS in streptozotocin-induced diabietic rats. Korean J Pharmacogn, 35, 300-308

10. Yao CZ, Li F, Liu YL, Zhang ZD, Wang JW, Cai BJ, Liu YY, Cheng JH, Zhao SL (1981) Influence of Chinese herb Lysimachia christinae Hance on immune responses in mice I. Immunosuppressive effect. Zhongguo Yi Xue Ke Xue Yuan Xue Bao, 3, 123-126

11. Gu LZ, Zhang BS, Nan, JH (1988) Anti-inflammatory effects of two species of Lysimachia christinae Hance and Desmodium styracifolium (Osbeck) Merr. Zhong Yao Tong Bao, 13, 40-42

12. Shoji N, Umeyama A, Takemoto T, Kobayashi M, Ohizumi Y (1984) $\mathrm{Na}^{+-\mathrm{K}+-A T P a s e}$ inhibitors from Lysimachia japonica. J Nat Prod, 47, 530-532

13. Hirayama $H$, Wang $Z$, Nishi $K$, Ogawa $A$, Ishimatu $T$, Ueda S, Kubo T, Nohara T (1993) Effect of Desmodium styracifolium-triterpenoid on calcium oxalate renal stones. Br J Urol, 71, 143-147

14. Kim HY, Kim SS, Lee CK, Choi JW (1996) Biological activities of Lysimachiae herba. I. Effects of the pretreatment of Lysimachiae herba on the enzyme activities in galactosamine intoxicated rats. Korean $\mathbf{J}$ Pharmacogn, 27, 58-64

15. Ryoo HS, Nam JY, Jeong JH, In MK, Ro SH Yook CS (2000) Studies on chemical components of the aerial part of Glechoma hederacea var. longituba. Kyung Hee pharmaceutical science, 28, 25-32

16. Folin Otto, Denis W (1912) On phosphotungsticphosphomolybdic compounds as color reagents. J Biol
Chem, 12, 239-243

17. Blois MS (1958) Antioxidant determination by the use of a stable free radical. Nature, 181, 1199-1200

18. Fellegrin N, Ke R, Yang M, Rice-Evans C (1998) Screening of diatary carotenoids and carotenoid-rich fruit extracts for antioxidant activities applying 2,2'-azinobis (3-ethylenebenzothiazoline-6-sulfonic acid) radical cation decolorization assay. Methods Enzymol, 299, 379-389

19. Andarwulan N, Shetty K (1999) Phenolic content in differentiated tissue cultures of untransformed and Agrobacterium-transformed roots of anise (Pimpinella anisum L.). J Agric Food Chem, 47, 1776-1780

20. Buege JA, Aust SD (1978) Microsomal lipid peroxidation. Methods Enzymol, 52, 302-310

21. Hearing VJ (1987) Mammalian monophenol monooxygenase (tyrosinase): Purification, properties, and reactions catalyzed. Methods Enzymol, 142, 154-165

22. Dorfman A, OTT ML (1948) A turbidimetric method for the assay of hyaluronidase. J Biol Chem, 172, 367-375

23. Kim AJ, Han MR Lee SJ (2012) Antioxidative capacity and quality characteristics of Yanggaeng using fermented red ginseng for the elderly. Korean J Food Nutr, 25, 83-89

24. Kim HJ, Jun BS, Kim SK, Cha JY, Cho YS (2000) Polyphenolic compound content and antioxidative activities by extracts from seed, sprout and flower of safflower (Carthamus tinctorius L.). J Korean Soc Food Sci Nutr, 29, 1127-1132

25. Jeong MK (2010) Monitoring the changes of 2,2-diphenyl-1-picrylhydrazyl (DPPH) absorbance and oxidation products in thermally oxidized linoleic acid. Seoul National University, Korea, p 5-6

26. Kim CK, In MJ, Kim DC (2015) In vitro Antioxidant activity of ethanol extract from Boehmeria nivea L. leaves. Food Eng Prog, 19, 76-81

27. Bae JS, Kim TH (2011) Pancreatic lipase inhibitory and antioxidant activities of Zingiber officinale extracts. Korean J Food Preserv, 18, 390-396

28. Wettasinghe M, Shahidi F (1997) Antioxidant activity of preformed cooked cured-meat pigment in a $\beta$ -carotene/linoleate model system. Food Chem, 58, 203-207

29. Park HJ, Kang SA, Lee JY, Cho YJ (2012) Antioxidant activities of extracts from medicinal plants. Korean J Food Preserv, 19, 744-750

30. Chung JH, Ho JS, Moon CK (1990) Direct interaction of streptozotocin with TBA (thiobarbituric acid) in lipid 
peroxidation analysis. Korean J Food Hyg Saf, 5, 237-242

31. Jung MS, Lee GS, Chae HJ (2004) In vitro biological activity assay of ethanol extract of radish. J Korean Soc Appl Biol Chem, 47, 67-71

32. Choi SY, Kim YC, Chang BS (2011) Inhibitory efficacy of black tea water extract on melanogenesis in melan-a cells and its action mechanisms. Korean J Microscopy, 41, 169-177

33. Cabanes J, Chazarra S, Garcia-Carmona F (1994) Kojic acid, a cosmetic skin whitening agent, is a slow-binding inhibitor of catecholase activity of tyrosinase. J Pharm
Pharmacol, 46, 982-985

34. Yoon MY (2016) A study on peanut spouts extract as the anti-oxidant activity and the skin whitening cosmetic ingredients. Korean Soc Biotech Bioeng J, 31, 14-19

35. Jeong SJ, Ko YS, Ahn NH, Kim YC (1998) Hyaluronidase inhibitor from Uncariae Ramulus et Uncus. Korean J Pharmcogn, 29, 169-172

36. Cho KS (2015) Evaluation of Achyranthes japonica ethanol extraction on the inhibition effect of hyluronidase and lipoxygenase. J Life Sci, 25, 1370-1376 